\title{
METODE PELATIHAN BERNYANYI DAN BERCERITA PADA GURU-GURU TK/PAUD SE- ACEH BESAR DALAM MENDIDIK KREATIVITAS SENI PADA ANAK KAB. ACEH BESAR
}

\author{
Benni Andika \\ Benny Andiko \\ Dian Permata Sari
}

\author{
Institut Seni Budaya Aceh \\ Jl. Transmigrasi, Gampong Bukit Meusara, Kec. Kota Jantho, \\ Kab. Aceh besar. Provinsi Aceh. 23911 \\ benniandika@isbiaceh.ac.id \\ benniandiko@isbiaceh.ac.id \\ dianpermatasari@isbiaceh.ac.id
}

ABSTRAK

Pengabdian ini bertujuan untuk mengajarkan metode pelatihan bernyanyi dan bercerita pada guru-guru TK/Paud di Aceh Besar, dalam meningkatkan kreativitas seni pada anak. Pelatihan diharapkan memberikan dampak bagi keberlangsungan seni dan budaya. Anak-anak usia dini merupakan salah satu pendukung dalam mempertahankan seni yang berkembang saat ini, dan pelatihan bernyanyi dan bercerita menjadi pilihan media penyampaian nasehat dalam nilai-nilai moral. Diharapkan pelatihan ini dapat berkontribusi terhadap pengembangan materi pendidikan seni kemampuan guru TK/PAUD dalam aspek vocal dan kemampuan bercerita. Metode ini dilakukan dengan cmenerapkan pemahaman konsep, metode ceramah dan metode praktek. Pada hasil pelatihan memeprlihatkan peningkatan terhadap kemampuan guru-guru tersebut.

Kata Kunci: Bernyanyi; bercerita; guru; Aceh Besar 


\section{PENDAHULUAN}

Perkembangan ilmu pengetahuan dan teknologi informasi serta komunikasi pada belakangan ini semakin melaju pesat dan telah menjadi bagian yang tidak terpisahkan lagi dalam kehidupan manusia, khususnya masyarakat Indonesia. Fenomena yang terjadi pada masyarakat saat ini, memberikan konsekuensi terhadap realita sosial masyarakat yang semakin terjebak dakam persoalan individualisme yang secara perlahan akan melenyapkan seni dan budaya yang tidak ternilai harganya. Terlebih berkembangnya teknologi yang begitu cepat perkembangannya dan memasuki pikiran anak-anak yang masih dibilang belia dan penting kita arahkan pada kegiatan yang memberikan dampak baik bagi mereka. Dampak baik tersebut adalah memberikan pendidikan seni pada anak-anak kita sejak dini, agar mereka dapat mengembangkan seni dengan baik dan dunia teknologi dapat dibatasi dengan hadirnya sebuah kreativitas seni yang terdapat dalam diri anak.

Pendidikan seni sangat penting untuk ditumbuh kembangkan pada anakanak kita, Sebab periodisasi perkembangan seni di Indonesia sangat sulit. Apalagi kurangnya perhatian pemerintah saat ini akan kemajuan pendidikan seni dan memajukan penggiat- penggiat seni di Indonesia, khususnya di Aceh. Yus Rusyana
(1993:5) guru besar pada FPBS serta staf pengajar Program Pasca Sarjana Universitas Pendidikan Indonesia mengungkapkan ; Hakekat Pendidikan Kesenian apabila dihubungkan dengan tujuan pendidikan Hal| 101 nasional pada dasarnya adalah (1) peserta didik memperoleh pengalaman seni yaitu pengalaman berapresiasi seni dan berekspresi seni, (2) peserta didik memperoleh pengetahuan seni yaitu teori seni dan sejarah seni. Di antara kedua tujuan itu yang utama beroleh pengalaman seni, sedang tujuan kedua adalah merupakan penunjang agar peserta didik peroleh pengalaman yang disertai pemahaman sehingga pengalamannya itu lebih jelas, lugas, dan berfungsi dalam kehidupannya (Juju Masunah dan Tati Narawati 2003: 257).

Pendidikan anak usia dini yang kerap disebut the golden age (usia emas) dan juga critical period (periode kritis) adalah pendidikan yang sangat penting dan sangat mendasar. Inilah tahun-tahun formatif atau pembentukan kepribadian yang amat menentukan perkembangan dan pertumbuhan anak selanjutnya (Putu et al., 2017). Pendidikan seni di taman kanakkanak merupakan bahagian dari proses pembentukan individu yang utuh sesuai dengan tujuan pendidikan nasional, pendidikan yang akan itu sendiri terdiri dari 
bernyanyi dan bercerita. Perlu dicermati bahwasannya pembelajaran seni untuk TK/PAUD untuk menciptakan senimanseniman cilik dan menawarkan sejumlah pengalaman yang bermanfaat untuk mengasah pribadi yang apresiasif dan kreatif melalui pendidikan seni. Kegiatan seni yang akan didapatkan anak usia dini akan memberikan dampak yang baik bagi keberlangsungan seni dan budaya.

Kabupaten Aceh Besar menjadi pilihan untuk kegiatan pelatihan Pendidikan seni. Pelatihan anak-anak TK atau pun Paud tidak menjadi peserta pelatihan, tetapi kegiatan ini lebih ditujukan pada gurugurunya. Karena guru adalah sebagai ujung tombak, agar anak-anaknya dapat mengenal dunia seni dengan baik. Guru-guru tersebut secara psikologis lebih dekat dengan anak didiknya dan lebih mudah mengaplikasikan ilmu pelatihan seni pada anak didiknya.

Berdasarkan penjabaran di atas dapat kita simpulkan bahwasannya sistem pendidikan seni masih kurang teraplikasi dengan baik dalam pengembangan anak didik seni, Khususnya dalam bidang bernyanyi dan bercerita. Begitu penting rasanya untuk ditumbuh kembangkan ilmu tentang seni bercerita dan bernyanyi kepada guru-guru yang mengajar di sekolah TK dan PAUD, dan menjadi tugas penting bagi guru-guru TK dan Paud mengajarkan sejak dini pada anak-anaknya bagaimana seni bercerita dan bernyanyi dengan baik dan benar.

Di Indonesia, sebelum pendidikan seni dikenalkan di sekolah ada cara mengalihkan keterampilan secara ketukangan (crafmanship) seorang seniman/kriyawan dalam hal ini orang tua kepada anak dengan cara pewarisan. Cara pewarisan ini bagi orang tua merupakan kebanggaan. Cara ini bagi lingkungan masyarakat didukung dan dilakukan untuk menurunkan seni kepada anak-anaknya. Walaupun tidak semua anak mewarisi bakat orang tuanya, namun baknyak realita yang tersibak, bahwa faktor internal yang kuat ditambah faktor gen sangat mempengaruhi minat anak untuk mendapatkan pewarisan seni dari orang tuanya.

Anak-anak usia dini merupakan salah satu pendukung dalam mempertahankan seni yang berkembang saat ini. menjadi pilihan media menyampaikan nasehat dalam nilai-nilai moral. Hal ini merupakan suatu upaya pendidikan seni dapat dipelajari oleh guru-guru TK dan PAUD dan mengajarkan ke anak-anaknya, khususnya di Kabupaten Aceh Besar. Wilayah ini merupakan bagian dari wilayah Nangroe Aceh Darusaallam, merupakan daerah yang memiliki TK/Paud dengan aktifitas baik. Bahkan setiap tahunnya 
TK/Paud Aceh Besar di bawah kendali Dinas Pendidikan Aceh Besar menyelenggarakan kegiatan lomba seni bagi anak anak TK/Paud. Kegiatan tersebut diselenggarakan sebagai bentuk apresiasi kepada siswa TK/Paud, anak-anak dilatih beragam kegiatan, mulai dari bernyanyi, menari dan bercerita.

\section{METODE PENGABDIAN}

\section{A. Pemahaman konsep}

Metode adalah cara yang digunakan untuk melaksanakan rencana yang sudah disusun dalam kegiatan nyata agar tujuan yang telah disusun tercapai secara optimal. Dengan demikian, metode dalam rangkaian sistem pembelajaran memiliki peran yang penting. Keberhasilan pelaksanaan strategi pembelajaran sangat tergantung pada cara guru menggunakan metode pembelajaran, karena suatu strategi pembelajaran hanya mungkin dapat dilaksanakan melalui penggunaan metode pembelajaran (Wina Sanjaya 2006:147). Tahapan ini di mulai dengan menggunakan metoda pengembangan kapasitas guru dalam membelajari teori seni dan bagaimana mengaplikasikannya pada anak. Pengembangan kapasitas guru merupakan upaya berkelanjutan yang dilakukan guru bersama sekolah dan pemangku kepentingan untuk terus menerus mengembangkan diri untuk menuju kualitas idealnya sebagai guru profesional yang dapat menginspirasi pencapaian prestasi optimal peserta didik (Khoiruuddin Bashori,dkk 2015:1).

Kapasitas itu didapatkan melalui pelatihan-pelatihan yang dilakukan narasumber untuk guru pendidik, sistem pengembangan guru ini harus dilakukan secara kontiniu. Agar guru-guru pendidik selalu mendapatkan keahlian sembari perkembangan zaman. Metode yang akan digunakan dalam pelatihan bernyanyi dan bercerita pada guru TK/PAUD se-Aceh Besar ini yaitu metode ceramah dan praktek. B. Metode Ceramah

Metode ceramah salah satu metode untuk menyampaikan informasi atau materi pelajaran kepada siswa dalam kegiatan pembelajaran. Seperti yang dikemukakan oleh Wina Sanjaya, metode ceramah adalah penerangan dan penuturan secara lisan dari guru terhadap siswanya, sedangkan peranan siswa mendengarkan dengan teliti, serta mencatat yang pokok dari yang dikemukakan oleh guru (Wina Sanjaya 2006:148. Instruktur menjelaskan dan menerangkan materi dengan menggunakan metode ceramah kepada guru. Metode ceramah digunakan dalam penyampaian awal materi kepada seluruh guru TK-PAUD 
se Kabupaten Aceh Besar, materi bernyanyi dan bercerita akan diajarkan secara bergantian.

\section{Metode Praktek}

Metode praktek yang dimaksud adalah metode demonstrasi cara menyampaikan materi dengan mempraktekkan materi pelajaran yang diberikan, atau memberi contoh sebelum peserta pelatihan disuruh mempraktekkannya. Bahwa metode ini memerlukan persiapan pra kondisi sebelum praktek kepada peserta, dan kemudian diperlukan media penghubung agar terjadinya komunikasi aktif. Inilah yang dimaksud dengan metode demonstrasi bahwa sebelum melakukan kegiatan pembelajaran peneliti mempersiapkan alat belajar yang akan digunakan dalam pembelajaran. Selama pembelajaran berlangsung dilakukan pengamatan. Selama guru mendemonstrasikan kegiatan bercerita di depan kelas, semua anak memperhatikan dengan baik (Susanti, 2019). Ini sejalan dengan metode drill yang dijelaskan oleh Enrico bahwa bahwa metode ini yaitu suatu metode yang diberikan kepada anggota/peserta agar materi yang sudah diajarkan diulang di rumah, sehingga anggota atau peserta menguasai penampilan cerita yang telah diajarkan secara baik dan benar (Alamo et al., 2018). Seperti yang dijelaskan Muhibbin Syah, metode demonstrasi adalah metode pembelajaran dengan memperagakan dan mempertunjukan kepada siswa tentang suatu proses, situasi atau benda tertentu, baik sebenarnya atau hanya sekedar tiruan. Sebagai metode penyajian, demontrasi tidak terlepas dari penjelasan secara lisan oleh guru (Muhibbin Syah 2000:208). Metode ini sangat efektif diaplikasikan dalam pelatihan bernyanyi dan bercerita karena peserta melihat secara langsung materi dari instruktur.

\section{HASIL PEMBAHASAN}

Melihat banyaknya minat seni pada anak-anak TK/Paud se Kabupaten Aceh Besar terutama pada gugus wilayah I-IV ( Seulimum, Jantho, Seulawah dan Kuta Cot Glie), maka Dinas Pendidikan mengedepankan kegiatan lomba seni ini diselenggarakan tiap tahun. Mereka berharap ada cabang lomba bernyanyi dan bercerita di samping lomba menari yang telah di agendakan pada tahun sebelumnya. Namun, kegiatan ini terkendala sebab sangat minim pelatih dan fasilitator yang bersedia mengadakan dalam bentuk workshop kepada guru-guru TK/Paud.

Berdasarkan hal tersebut, maka pada kegiatan pengabdian kepada masyarakat yang di danai oleh LPPMPMP ISBI Aceh 
tahun ini, Tim pengabdian mengadakan kegiatan pengabdian dalam bentuk metode pelatihan bernyanyi dan bercerita pada Guru-Guru TK/Paud se-Aceh Besar dalam mendidik kreatifitas seni pada anak Kabupaten Aceh Besar.

\section{A. Bernyanyi}

Materi ceramah terkait pemahaman dan pelaksanaan proses olah vokal, yang semuanya itu bermaksud dan bertujuan agar diketahui cara bagaimana memproduksi dan membentuk suara yang baik dan benar. Proses olah vokal dan keterampilan memproduksi dan membentuk suara itu dengan teknik vokal yang benar, menjadi pokok materi ceramah yang disebut prosedur atau langkah-langkah memproduksi dan membentuk suara. Materi pertama yaitu artikulasi dan pernafasan. Artikulasi adalah cara pengucapan kata demi kata yang baik dan jelas. Pernafasan adalah usaha untuk menghirup udara sebanyak-banyaknya, kemudian disimpan, dan dikeluarkan sedikit demi sedikit sesuai dengan keperluan. Pernafasan di bagi tiga jenis, yaitu : pernafasan dada : cocok untuk nada-nada rendah, penyanyi mudah lelah. Pernafasan perut : udara cepat habis, kurang cocok digunakan dalam menyanyi, karena akan cepat lelah. Pernafasan diafragma : adalah pernafasan yang paling cocok digunakan untuk menyanyi, karena udara yang digunakan akan mudah diatur pemakaiannya, mempunyai power dan stabilitas vokal yang baik. Teknik pernafasan vokal yang standar dan umum digunakan, yaitu teknik pernafasan Hal| 105 diafragma. Phrasering adalah : aturan pemenggalan kalimat yang baik dan benar sehingga mudah dimengerti dan sesuai dengan kaidah-kaidah yang berlaku. Sikap badan : adalah posisi badan ketika seseorang sedang nyanyi, bisa sambil duduk, atau berdiri, yang penting saluran pernafasan jangan sampai terganggu. Resonansi adalah : usaha untuk memperindah suara dengan mefungsikan rongga-rongga udara yang turut bervibrasi/ bergetar di sekitar mulut dan tenggorokan. Vibrato adalah : Usaha untuk memperindah sebuah lagu dengan cara memberi gelombang/ suara yang bergetar teratur, biasanya di terapkan di setiap akhir sebuah kalimat lagu. Improvisasi adalah usaha memperindah lagu dengan merubah/menambah sebagian melodi lagu dengan profesional, tanpa merubah melodi pokoknya. Intonasi adalah tinggi rendahnya suatu nada yang harus dijangkau dengan tepat. Syarat-syarat terbentuknya intonasi yang baik yaitu pendengaran yang baik, kontrol pernafasan dan rasa musical.

Nada adalah bunyi yang memiliki getaran teratur tiap detiknya. Sifat nada ada 
4 yaitu: pitch: yaitu ketepatan jangkauan nada, durasi : yaitu lamanya sebuah nada harus dibunyikan, intensitas nada : yaitu keras/lembutnya nada yang harus dibunyikan, Timbre : yaitu warna suara yang berbeda tiap-tiap orang. Ambitus suara adalah luas wilayah nada yang mampu dijangkau oleh seseorang. Seorang penyanyi profesional harus mampu menjangkau nadanada dari yang paling rendah sampai yang paling tinggi sesuai dengan kemampuannya.

Crescendo adalah suara pelan berangsur-angsur keras. Descrescendo adalah suara keras berangsur-angsur pelan. Stacato adalah suara dalam bernyanyi yang terpatah-patah. Suara manusia dibagi tiga : suara wanita dewasa yaitu Sopran (suara tinggi wanita) Messo Sopran (suara sedang wanita) Alto (suara rendah wanita), suara pria dewasa yaitu Tenor (suara tinggi pria) Bariton (suara sedang pria) Bas (suara rendah pria), suara anak-anak : yaitu tinggi dan rendah. Berdasarkan semua materi yang disampaikan melalui ceramah, yaitu pemahaman dan kemampuan memproduksi suara. Dilandasi teknik dasar yang benar dan baik, untuk dikembangkan oleh guru-guru TK/PAUD se-Aceh Besar dalam mendidik kreatifitas seni pada anak khususnya bernyanyi.

Materi praktek pertama, yaitu teknik pernafasan teknik pernafasan ini merupakan motor penggerak. Dalam bernyanyi, pernafasan itu sangat penting karena bernafas dengan baik akan sangat membantu dalam membentuk suara serta dapat memenuhi prasering atau panjang dan pendeknya suatu kumpulan nada, ada bermacam-macam olah pernafasan, yaitu : pernafasan claviculair (dengan memakai pundak), pernafasan costrol (dengan dada), pernafasan diafragma (ini yang paling baik). proses atau cara melatih pernafasan yang baik dan benar : Pernapasan yang buruk akan mengakibatkan produksi suara yang buruk, teknik pernapasan yang tidak benar akan menghasilkan suara yang tidak berkualitas. Menghirup napas yang baik untuk menyanyi adalah menggunakan mulut dan hidung secara Bersama-sama, terutama pada waktu menghirup dengan cepat dan dalam jumlah yang banyak.

Cara bernafas yang baik pada saat bernyanyi sebagai berikut : jangan menggunakan cara pernapasan di mana pada waktu menghirup udara, dada dan bahu terangkat, ini membuat leher menjadi tegang dan mengganggu produksi suara. Pada waktu bernapas daerah sekitar lingkar perut mengembang dan pada waktu membuang napas mengempis. Pada waktu menghembuskan napas untuk memproduksi suara, otot-otot di sekitar perut mengencang dan secara konstan mendorong ke dalam 
(mengempis) dengan berlahan-lahan dan terus-menerus sampai kalimat lagu habis. Ini yang disebut support dan sustain. tarik nafas atau hirup nafas anda dalam 8 hitungan $(8$ detik) : 12345678 . tahan nafas dalam 4 hitungan (4 detik) : 1234 . Keluarkan nafas anda dengan berdesis ( suara ular) dalam 8 hitungan : 12345678 . Bisa juga hal itu disebut 848 karena menghirup nafas dalam 8 hitungan, menahan nafas dalam 4 hitungan dan mengeluarkan nafas dalam 8 hitungan. Lakukan latihan itu berulang-ulang, dan saat mengeluarkan nafas, desis anda bisa diganti dengan mengucapkan mo atau me atau mu.

Intonasi (Penguasaan Notasi). Intonasi adalah pembidik nada yan tepat atau menyanyikan nada dengan tepat. Untuk bisa memiliki intonasi yang baik, kita sebaiknya berlatih dengan alat musik seperti piano atau keyboard supaya nada yang kita mainkan pasti dan terkontrol. Tapi hal ini dapat diakali jika kita tidak memiliki alat musik tersebut. Kita bisa merekam suara piano tersebut di handphone kita dan kita dapat pelajari sewaktu-waktu. Irama, Birama dan Tempo. Seorang penyanyi yang baik seharusnya belajar untuk bisa menguasai bermacam-macam irama atau jenis aliran music seperti : Chaca, Pop, Waltz dan sebagainya. Dia juga harus mengetahui birama lagu, apakah 4/4 atau 2/4, dan mesti mengikuti tempo (lambat-cepat) lagu.
Penguasaan Artikulasi (pengucapan kata). Seorang penyanyi selain harus menguasai dan mengahfalkan syair (lirik) lagu dengan baik, juga harus mengucapkan kata-katanya dengan jelas dan tegas. Untuk Hal| 107 membantu agar dapat member jiwa pada lagu tersebut, harus juga memahami isi dan maksud yang terkandung dalam lagu. Ada beberapa cara praktis untuk meningkatkan artikulasi anda, yaitu dengan mengucapkan vocal : A I U E O. Teknik Vibrasi. Vibrasi adalah suatu bentuk suara yang bergetar dan bergelombang dalam tehnik oleh vokal, vibrasi ini merupakan tahap finishing. Fungsinya biar terdengar lebih merdu dan indah. Kalau mau tahu contoh vibrasi yaitu ketika seseorang tertawa terbahak-bahak, suara akan terdengar bergetar dan bergelombang. Kemudian dalam dunia tarik suara, bentuk dasar tersebut dikembangkan menjadi sebuah tehnik dalam bernyanyi yang disebut vibrasi.

Sikap tubuh dan kondisi saat menyanyi. Selain hal-hal diatas, ada hal lain yang harus diperhatikan, yaitu sikap tubuh dalam bernyanyi, baik dalam latihan maupun pada saat kita sedang tampil di panggung/podium. Mengapa sikap tubuh sangat berpengaruh pada sirkulasi nafas yang merupakan unsur penting dalam bernyanyi. Sikap ini harus dilatih, baik sikap duduk maupun sikap berdiri. sikap tubuh 
sangat mempengaruhi produksi suara seorang penyanyi baik penyanyi solo maupun penyanyi paduan suara. Pada saat menyanyi tubuh harus dalam kondisi yang rileks (bukan santai). Tubuh yang rileks dimaksudkan agar suara yang dihasilkan juga rileks dan tidak tegang. Untuk menciptakan suasana yang rileks sebelum bernyanyi diperlukan suatu relaksasi atau pelemasan tubuh dengan cara bersenam, memijat, dll. Relaksasi perlu dilakukan pada saat latihan dan juga pada setiap sebelum penampilan, apalagi pada saat berlomba. Mental yang tegang mengakibatkan tubuh menjadi tegang pula, sehingga suara yang dihasilkan tidak maksimal. Posisi tubuh dalam menganyi harus mendapat perhatian. Posisi yang baik adalah berdiri dengan membagi beban yang sama pada dua kaki dan menempatkan kaki sedemikian rupa sehingga menjadi seimbang, terutama agar tubuh juga dapat ikut bergerak mengkespresikan dari lagu yang dinyanyikan. Pada posisi menyanyi sambil duduk, posisi tubuh bagian pinggang ke atas harus dalam kondisi yang sama dengan posisi tubuh bagian pinggang ke atas pada saat sedang berdiri. Posisi tubuh yang gagah sangat dibutuhkan. Ekspreasi wajah pada saat menyanyi juga sangat menentukan. Pada saat mengambil nada-nada yang tinggi perlu konsentrasi dalam menyanyikannya, maka alis dapat dinaikan, serta pipi seperti seorang yang sedang tersenyum dan jangan lupa untuk membuka mulut yang lebar sesuai dengan ketentuan yang biasa dilakukan dalam menyanyi. Pada saat menyanyi memang nampak wajah akan terlihat jelek, namun suara yang dihasilkan akan jauh lebih berkualitas dibandingkan dengan kalau kita menyanyi hanya ingin menampilkan penampilan saja.

Relax, seluruh badan mulai dari kepala sampai ujung kaki harus diberi latihan supaya santai. Tes potensi dengan latih bagian rahang dengan huruf-huruf vokal dan konsonan. (Ingat, rahang harus relaks) A i u e o latihan diafraghma: huruf kch-k-ch-sssst-th. Dengan tempo cepat. Hoho-ho...ha-ha-ha lalu latihan wilayah nasal (hidung): "nya-nya-nya" dengan benarbenar menekankan suara cempreng dari hidung. Lalu latihan bibir nyanyikan tangga nada dengan bibir terkatup jadi bunyinya bakal "brrrrr-brrrr-brrr-brrr" nyanyikan tangga nada, arpeggio, secara staccato (patah) maupun legato. Latihan lidah "la-lala. Ra ra ra, tatata.". Dilatih semuanya menggunakan tangga nada dan arpeggio. 


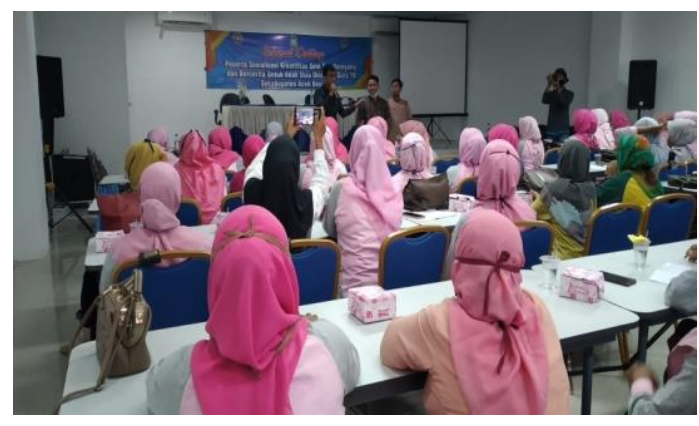

Gambar 1.

Narasumber memberikan materi bercerita kepada peserta.

(Dokumentasi Dok. Rolli, 2020)

\section{A. Bercerita}

Lomba bercerita yang selalu didakan pemerintah daerah Aceh Besar di setiap tahunnya menjadi tantangan pada guru-guru TK/Paud dalam membelajari bagaimana mengajatkan anak dalam mempertunjukan sebuah karya bercerita di depan para penonton dan para juri.

Pelatihan yang sudah dilakukan pada guru ini bertujuan untuk mengembangkan Pengetahuan dan keterampilan guru dalam melatih anak didiknya ketika bercerita, sehingga diharapkan seorang guru memperoleh keunggulan yang kompetitif dalam memberikan pelayanan dengan sebaikbaiknya, meningkatkan kemajuan belajar dan anak memiliki dorongan kreativitas dari pembelajaran dan pembibimbingan yang dilakukan gurunya serta dapat meningkatkan kinerja. Sebelum anak didiknya diajarkan bagaimana metoda bercerita, maka guru harus terlebih dahulu menguasai metode dalam mengajak anak bercerita. Banyak juga guru yang belum bisa mempraktekkan bagaimana bercerita dan bagaimana mengajarkan keada anak didiknya. Malah ketika dalam pelatihan, guru-guru masih malu-malu dan hanya mengeluarkan suara datar, tidak berekspresi, dan tidak ada intonasi.

Beberapa pendekatan dan sistematis yang dilakukan narasumber dalam pelatihan ini, Tahap pertama mengenali peserta dan kebutuhannya, tahap kedua memberikan pelatihan terhadap apa yang akan di ajarkan dan apa yg menjadi kebutuhan utama bagi peserta. Selanjutnya Cerita merupakan salah satu bentuk sastra yang dimiliki keindahan dan kenikmatan tersendiri, akan sangat mengyenangkan bagi anak-anak dan orang dewasa. Cerita adalah salah satu bentuk sastra yang dapat dibacakan dan didengar. Metode bercerita adalah salah satu cara menyampaikan informasi dalam proses pembelajaran, khususnya pada anak usia dini (Nurbiana, 2007). Cerita yang disampaikan harus menarik dan mengundang perhatian anak dan tidak lepas dari tujuan Pendidikan ank TK/Paud. Bahkan ada pakar yang berpendapat 
bercerita adalah metode yang sangat baik dalam mengajar (Latif,2012).

Pelatihan metode bercerita dan bernyanyi ini harus dilakukan, agar guruguru TK/Paud dapat mempelajarinya dengaan baik dan benar serta mengaplikasikannya kepada anak didik. Beberapa Teknik-teknik yang dilakukan seseorang dalam bercerita adalah sebagai berikut. Pertama, Posisi atau tempat. Bercerita harus ditempat yang tepat sehingg semua audiens dapat melihat dengan jelas. Kedua, Suara harus lantang dan Jelas, agar dapat didengar semua audiens lainnya dengan jelas. Ketiga, Penguasaan materi cerita. Agar ceritanya sampai kepada audiens, terlebih dahulu si pencerita menguasai cerita yang akan dia ceritakaan, sehingga dia tahu kapan intonasi berubah, dan kapan menciptakaan irama pada cerita sert ekspresi yang akan diciptakan. Keempat, penjiwaan. Seseorang dalam bercerita hrus menjiwai cerita yang akan dibawakaan, karena setiap dialog yang dikeluarkan dapat membangun suasana yang diharapkan serta penonton masuk dan menikmati peristiwa. Kelima, mencipta Suara. Seseorang pencerita dapat menciptakan (menirukan) tokoh apa dalam cerita. Apakah manusia atau binatang, dapat menirukan dengaan cara merubah suaranya. Keenam, gerakan. Tubuh harus melakukan gerakaan atau membangun gestur, agar cerita lebih menarik diperhatikan.

Dengan beberapa Teknik pembelajaran yang sudah dijelaskan di atas, guru-guru dapat mengaplikasikannya bagaimana metode dalam mengajarkan anak didik dalam bercerita pada audiens. Metoda bercerita merupakan juga salah satu pemberian pengalaman bagi anak TK/Paud dengan membawakan secara lisan. Cerita yang diajarkan nanti haarus mengundang perhatian anak untuk belajar dan tidak terlepas pada tujuan pendidikan anak didik. Usahkan cerita yang diberikan pada anak didik lebih bersifaat pengalaman mereka di sekolah dan kehidupan mereka, maka mereka akan mencoba untuk mendengarkan dan belajar. Dunia kehidupan yang penuh dengan suka dan cita, hiburan, lucu daan mengasyikan. Ketika memulai untuk mengajarkan anak dalam bercerita, gunakan cerita yang memiliki gambar, memiliki warna, dan meminta mereka juga membacanya.

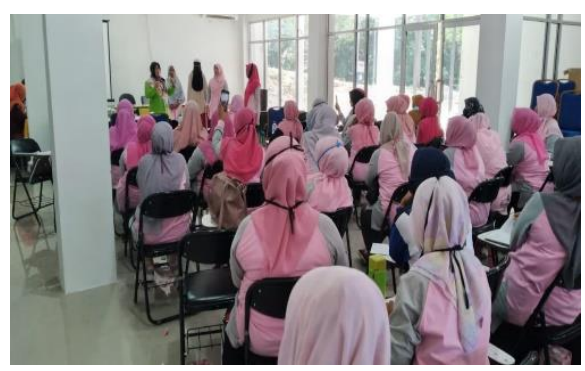

Gambar 1.

Narasumber memberikan materi bercerita kepada peserta.

(Dokumentasi Dok. Rolli, 2020) 


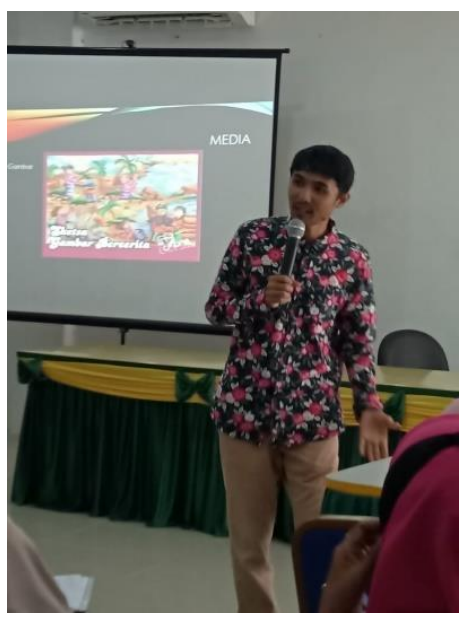

Gambar 3.

Narasumber memberikan materi bercerita kepada peserta.

(Dokumentasi Dok. Rolli, 2020)

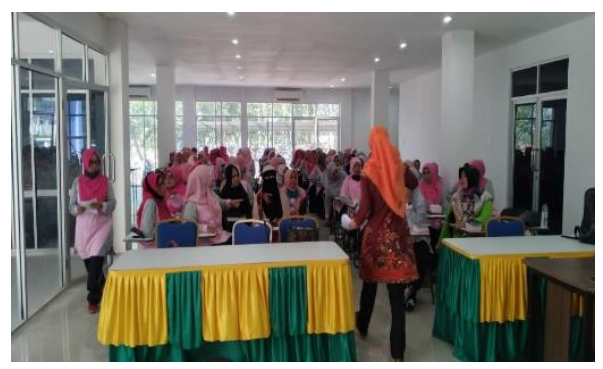

Gambar 4.

Narasumber memberikan materi bercerita kepada peserta.

(Dokumentasi Dok. Rolli, 2020)

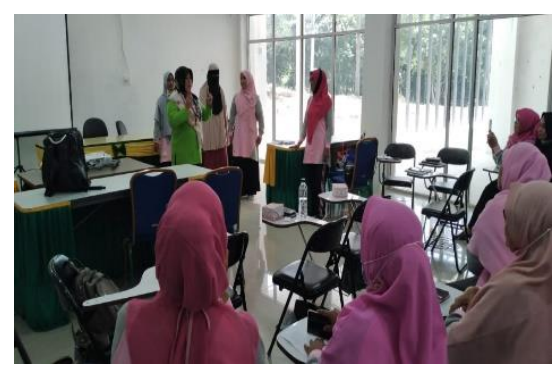

Gambar 5.

Narasumber memberikan materi bercerita kepada peserta.

(Dokumentasi Dok. Rolli, 2020)

\section{SIMPULAN}

Berangkat dari kerja yang dilakukan dimasa covid 19 ,

kegiatan tetap dilakukan dengan mematuhi protokol kesehatan.

Mengutamakan kesehatan dan peserta menjaga jarak dengan peserta lainnya. Kegiatan dapat terlaksana dengan baik dan materi yang disampaikan kepada guru TK dan Paud dapat diterima dengan baik oleh peserta, dari kegiatan ini juga mendapat apresiasi dari Kepala Dinas Pendidikan dan Kebudayaaan Aceh Besar.

Pelatihan bercerita dan bernyanyi yang dilakukan dapat memberikan motivasi guru-guru TK/Paud untuk selalu belajar dan selalu meningkatkan kinerjanya di mulai dari anak usia dini. Semoga pelatihan pembelajaran seni bernyanyi dan bercerita pada guru-guru nantiknya memberikan pengaruh yang besar akan perkembangan seni di Kabupaten Aceh Besar pada khususnya dan Indonesia pada umumnya. Pelatihan ini sebagai stimulus pengembangan imajinasi bagi dalam ruang lingkup seni pertunjukan.

Dalam hal ini terkait dengan pembelajaran bernyanyi dan bercerita yang output dari kegiatan tersebut yaitu pertunjukan. Hal ini secara tak langsung berimplikasi pada penguatan mental siswa didik dalam pengembangan seni budaya. 
Metode pembelajaran yang tepat harus dimiliki oleh guru-guru TK/Paud agar aspek kognitif pembelajaran tercapai dan sesuai dengan yang diharapkan.

\section{KEPUSTAKAAN}

Alamo, E., Susanti, D., \& Saaduddin, S. (2018). PELATIHAN KELOMPOK SANDIWARA DAN PEMANTAPAN MANAJEMEN KELOMPOK DI KELURAHAN GANTING PADANGPANJANG, SUMATERA BARAT. Batoboh, 3(1), 37-47. https://doi.org/10.26887/bt.v3i1.377

Putu, P. D. N., I Made Tegeh, \& Putu Rahayu Ujianti. (2017). Efektivitas Metode Bercerita Dengan Media Boneka Wayang Terhadap Kemampuan Bercakap-Cakap Anak Kelompok B Di TK Widya Sesana Sangsit Tahun Pelajaran 2016/2017. Jurnal Pendidikan Anak Usia Dini Undiksha, 5(3), 336-347.

Susanti, E. D. (2019). Meningkatkan Kemampuan Bercerita Anak Melalui Metode Demonstrasi Pada Anak Kelompok B Di TK. 2(1), 6.

Masunah, Juju. (2003) Seni dan Pendidikan Seni. Bandung : Pusat Penelitian PAST UPI.
Latif, M. A. (2012). The Miraacle of Story Telling. Jakarta : Zikrul https://media.neliti.com/media/publications/ 259946-hubungan-pelatihan-berceritaterhadap-ke-cc3abf95.pdf

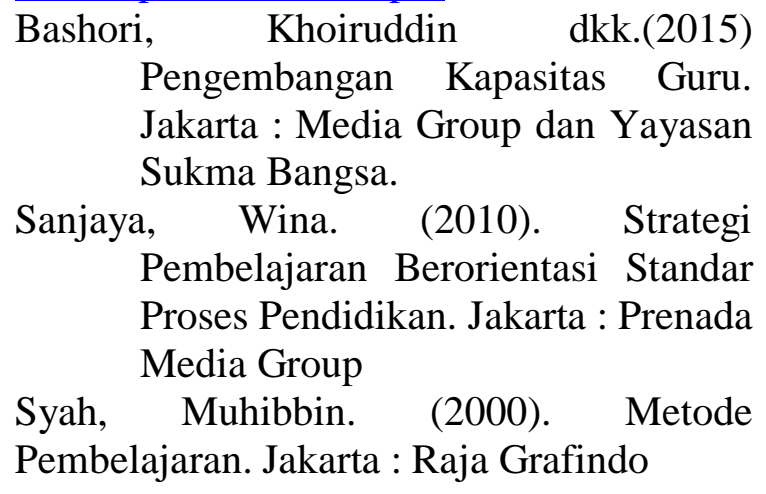
Pengembangan Kapasitas Guru. Jakarta : Media Group dan Yayasan Sukma Bangsa.

Pembelajaran Berorientasi Standar Proses Pendidikan. Jakarta : Prenada Media Group

Pembelajaran. Jakarta : Raja Grafindo 